\title{
PENGARUH ENDORSEMENT FASHION BLOGGER TERHADAP MINAT BELI MEREK LOKAL PADA TAHUN 2013 - 2014 (STUDI KASUS PADA FASHION BLOGGER EVITA NUH)
}

Gevin Sepria Harly \& Damayanti Octavia

Prodi Manajemen Bisnis Telekomunikasi \& Informatika, Fakultas Ekonomi \& Bisnis, Universitas Telkom email: damavia@yahoo.co.id

\section{ABSTRAK}

Penelitian ini bertujuan untuk mengetahui bagaimana tanggapan responden mengenai endorsement fashion blogger dan minat beli, serta untuk melihat seberapa besar pengaruh erndorsement fashion blogger terhadap minat beli merek lokal secara parsial maupun simultan. Metode yang digunakan dalam penelitian ini adalah metode deskriptif kausal dan pendekatan kuantitatif. Hasil penelitian yang didapat menunjukkan bahwa Endorsement Fashion Blogger yang terdiri dari sub variabel Visibility, Credibility, Attraction, dan Power mendapat tanggapan responden sebesar $83,72 \%$ atau berada pada kategori sangat baik, sedangkan Minat Beli Merek Lokal mendapat tanggapan sebesar 75,4\% atau termasuk pada kategori baik. Besarnya pengaruh Endorsement Fashion Blogger terhadap Minat Beli Merek Lokal pada blog Evita Nuh setelah dilakukan pengujian ulang melalui trimming adalah secara simultan variabel Credibility dan Power memiliki pengaruh yang signifikan sebesar $37,4 \%$ sedangkan sebesar $62,6 \%$ dipengaruhi oleh variabel-variabel lain diluar penelitian ini.

Kata kunci : Endorsement Fashion Blogger, Minat Beli 
Perkembangan dunia fashion di Indonesia saat ini mengalami kemajuan yang sangat pesatdengan dukungan kreativitas dan inovasi designer-designer muda Indonesia dalam membuat karya-karya unik \& bernilai jual lebih di pasar Indonesia,(Sumber: http://forum.kompas.com diakses pada tanggal 1 juni 2013). Industri fashion merupakan sektor terbesar kedua yang harus dikembangkan. Sumbangan industri fashion pada tahun 2010 yaitu 128 triliun, dan pada 2012 menyumbang 264 triliun. Secara presentase, fashion menyumbang 7\% terhadap Produk Domestik Bruto (PDB) nasional. Sementara itu, penyerapan tenaga kerja bidang fashion pada tahun 2012 mencapai 3,8 juta orang dari 11, 8 juta pekerja, (sumber : budpar.go.id diakses pada tanggal 12 juni 2013). Hal ini berarti industri fashion semakin berkembang dari tahun ke tahun, sehingga mendorong munculnya designer-designer muda dari berbagai kota di Indonesia dengan merek lokal yang meramaikan industri fashion saat ini.

Merek lokal merupakan salah satu produk yang patut diperhitungkan, karena semakin lama merek lokal semakin banyak diminati, terbukti dengan semakin banyak merek lokal yang memasuki industri di Indonesia terutama Industri kreatif. Bahkan dengan didukung adanya internet, banyak merek lokal yang sudah bisa memasuki pasar global. Saat ini terdapat gerakan 100\% Cinta Indonesia yang juga di dukung oleh beberapa Badan Usaha Milik Negara, yang gencar disosialisasikan di media cetak seperti kompas. Serta media elektronik dengan iklan "aku cinta Indonesia" agar kita bangsa Indonesia lebih cinta terhadap produk lokal dibanding produk asing yang masuk ke pasar Indonesia, (sumber: kompas.com diakses tanggal 17 juni 2013).

Contoh nyata dari gerakan 100 persen cinta Indonesia di bidang fashion adalah dengan adanya event fashion seperti Jakarta Fashion Week, Indonesia Fashion Week, Trademark, Lookats Market, Pop Up Market, dan Brighspot Market sebagai bentuk apresiasi bangsa Indonesia untuk mendorong perkembangan dunia fashion lokal, dan memberikan kesempatan lebih banyak untuk merek lokal, sehingga bisa dikenal oleh masyarakat luas. Event - event ini sangat membantu meningkatkan kecintaan dan minat beli masyarakat Indonesia terhadap merek lokal, hal Ini dapat dilihat dari jumlah pengunjung yang datang ke event lokal ini.

Tabel. 1

Daftar jumlah pengunjung beberapa Event fashion

di Indonesia

\begin{tabular}{|c|c|c|c|c|}
\hline \multirow{2}{*}{ Event } & \multicolumn{2}{|c|}{$\begin{array}{c}\text { Jumlah } \\
\text { Pengunjung }\end{array}$} & \multicolumn{2}{c|}{ Jumlah tenant } \\
\cline { 2 - 5 } & 2012 & 2013 & 2011 & 2012 \\
\hline Trademark & 68.021 & 70.000 & 80 & 100 \\
\hline $\begin{array}{c}\text { Lookats } \\
\text { market }\end{array}$ & 30.000 & 58.000 & 50 & 70 \\
\hline $\begin{array}{c}\text { Brighspot } \\
\text { Market }\end{array}$ & 65.000 & 75.000 & 100 & 120 \\
\hline
\end{tabular}

(sumber : female.kompas.com, swa.co.id, redandwhitemag.com)

Selain didukung dengan adanya event fashion merek lokal yang masuk dalam industri fashion juga didukung dengan adanya concept store dan online store yang mau memasarkan produk dari merek lokal seperti The Goods Dept, Manekineko, Localbrand.co.id, Berrybenka.com, dan lain - lain. (sumber :http://mix.co.id diakses tanggal 4 juni 2013) Salah satu bentuk kegiatan pemasaran tersebut adalah periklanan dengan tujuan untuk meraih perhatian konsumen terhadap produk serta untuk mengkomunikasikan merek produk, membentuk identitas, dan menentukan citra produk yang diiklankan serta dapat menyampaikan suatu pesan iklan. Salah satu pendekatan 


\section{JURNAL}

MANAJEMEN

INDONESIA

Vol. 14. No. 2

Agustus 2014 periklanan yang dipakai oleh fashion merek lokal adalah endorsement fashion blogger, dimana merek lokal mengirim produk kepada fashion blogger, dan fashion blogger tersebut akan mempromosikan produk merek lokal tersebut di media media sosial, serta mereview produk lokal tersebut di blog mereka. Fashion blogger juga sering memakai produk tersebut di majalah - majalah remaja seperti go girl, girlfriend, dan hers magazine. Bahkan, sebuah survey dari bloger and global communication firm ketchum and conducted by Nielsen Company, menemukan 20 persen wanita yang menggunakan sosial media akan mempertimbangkan produk yang dipromosikan oleh atau dengan fashion blogger yang mereka lihat, sedangkan hanya 13 persen yang mempertimbangkan untuk membeli produk yang menggunakan selebriti endorsement, (http://www.businessnewsdaily.com diakses tanggal 28 mei 2013). Berikut adalah beberapa fashion blogger terkenal di Indonesia :

Tabel 2

\begin{tabular}{|c|c|c|}
\hline $\begin{array}{l}\text { Fashion } \\
\text { blogger }\end{array}$ & Alamat blog & $\begin{array}{c}\text { Jumlah } \\
\text { pengik } \\
\text { ut }\end{array}$ \\
\hline $\begin{array}{l}\text { Diana } \\
\text { Rikasari }\end{array}$ & $\begin{array}{l}\text { http://dianarikasari.blogspot } \\
\text {.com }\end{array}$ & $>10.000$ \\
\hline $\begin{array}{l}\text { Evita } \\
\text { Nuh }\end{array}$ & $\begin{array}{l}\text { jellyjellybeans.blogspot.co } \\
m\end{array}$ & 5.822 \\
\hline $\begin{array}{l}\text { Anastasia } \\
\text { Siantar }\end{array}$ & www.brownplatform.com & 4.146 \\
\hline $\begin{array}{l}\text { Michelle } \\
\text { hendra }\end{array}$ & $\begin{array}{l}\text { www.glistersandblisters.co } \\
\mathrm{m}\end{array}$ & 3.234 \\
\hline $\begin{array}{l}\text { Clara } \\
\text { Devi }\end{array}$ & www.luce-dale.com & 2.313 \\
\hline $\begin{array}{l}\text { Sonia } \\
\text { Eryka }\end{array}$ & soniaeryka.blogspot.com & 2.179 \\
\hline $\begin{array}{l}\text { Elle \& } \\
\text { Jess }\end{array}$ & elleandjess.blogspot.com & 1.228 \\
\hline Marcella & www.carolsletters.com & 830 \\
\hline $\begin{array}{l}\text { Adelle } \\
\text { Veronica } \\
\end{array}$ & $\begin{array}{l}\text { adelleveronica.blogspot.co } \\
m\end{array}$ & $>500$ \\
\hline
\end{tabular}

Dari tabel 2 tiga fashion blogger dengan pengikut terbanyak adalah Diana Rikasari, Evita Nuh, dan Anaztasia Siantar. Diana Rikasari jarang menerima endorsement merek lokal apalagi sepatu karena Diana adalah pemilik dari 2 sepatu merek lokal yaitu UP dan Popflats. Sedangkan Evita Nuh sering bekerjasama dengan berbagai produk fashion merek lokal yang sering ditampilkan di blog dan jejaring sosial milik Evita Nuh. Banyaknya merek lokal yang melebihi jumlah fashion blogger yang terkenal di Indonesia, membuat persaingan menjadi semakin ketat, kadang fashion blogger menerima banyak endorsement, sehingga keefektifan pendekatan periklanan ke fashion blogger patut dipertanyakan, apakah masih bisa menarik minat beli konsumen terhadap merek lokal yang dipakai oleh fashion blogger, serta seberapa besar pengaruh fashion blogger tersebut terhadap minat beli konsumen, yang secara tidak langsung akan berdampak kepada penjualan merek lokal itu sendiri. Berdasarkan latar belakang tersebut, maka penulis akan melakukan penelitian yang berjudul, "Pengaruh Endorsement Fashion Blogger terhadap Minat Beli Merek Lokal” (Studi Kasus pada Fashion Blogger Evita Nuh).

\section{Perumusan Masalah}

Dari uraian di atas, maka dapat dirumuskan permasalahan sebagai berikut : (1) Bagaimana tanggapan responden mengenai endorsement fashion blogger? (2) Bagaimana tanggapan responden mengenai minat beli merek lokal? (3) Seberapa besar endorsement fashion blogger mempengaruhi minat beli merek lokal? 
Tujuan penelitian ini adalah : (1) Untuk mengetahui bagaimana tanggapan responden mengenai endorsement fashion blogger. (2) Untuk mengetahui tanggapan responden mengenai minat beli merek lokal. (3) Untuk melihat seberapa besar pengaruh endorsement fashion blogger terhadap minat merek lokal.

\section{TINJAUAN PUSTAKA}

\section{Endorser}

Dalam pembuatan sebuah iklan diperlukan seseorang yang dapat menarik perhatian dan mampu menyampaikan pesan serta informasi sebuah produk yang biasanya dikenal dengan istilah Endorser. Penggunaan endorser dalam iklan dimaksudkan untuk memberikan dukungan atau dorongan kepada pesan iklan agar lebih mudah diterima oleh konsumen, sekaligus mempermudah tumbuhnya keyakinan dalam diri konsumen atas produk yang diiklankan. Menurut Shimp (2003:459) Endorser dapat dibagi menjadi dua kelompok, yaitu: (a) Celebrity Endorser : Celebrity Endorser adalah tokoh (aktor, penghibur, atau atlet) yang dikenal masyarakat karena prestasinya di dalam bidang-bidang yang berbeda dari golongan produk yang didukung. (b) Typical-person Endorser : Typical-person Endorser adalah orang-orang biasa (non selebriti), yang digunakan dalam mempromosikan suatu produk atau jasa tertentu oleh suatu perusahaan.Pemilihan jenis endorser ini biasanya digunakan sebagai bentuk promosi testimonial untuk meraih kepercayaan konsumen. Contohnya yang paling umum adalah dalam iklan layanan masyarakat yang cenderung menggunakan endorser tipe ini agar pesan yang disampaikan mudah dipahami dan dimengerti audiens karena diharapkan audiens merasa bahwa presenter pesan tersebut merupakan salah satu dari mereka.

\section{Celebrity Endorser}

Menurut Schiffman dan Kanuk (2010:287), daya tarik selebriti digunakan dengan sangat efektif oleh para pemasang iklan untuk berkomunikasi dengan pasar-pasar mereka. Para selebriti dapat menjadi kekuatan yang berpengaruh dalam menimbulkan minat atau tindakan yang berhubungan dengan pembelian atau penggunaan barang-barang dan jasa-jasa yang dipilih. Identifikasi tersebut didasarkan pada kekaguman (terhadap seorang atlit), aspirasi (seorang selebriti atau terhadap suatu gaya hidup), empati (terhadap seseorang atau situasi), atau pada pengakuan (terhadap seseorang - sejati atau meniru-niru - atau terhadap suatu situasi).

\section{Celebrity Endorser sebagai daya tarik pesan}

Perusahaan harus memiliki strategi yang kreatif dalam beriklan agak dapat menarik konsumen, salah satu caranya adalah dengan menggunakan selebriti endorser. Suyanto (2007: 99) mengatakan selebriti dapat mempengaruhi sikap dan pelanggan terhadap produk yang didukungnya.Persepsi dan sikap pelanggan terhadap kualitas produk meningkat dengan adanya selebriti yang mendukung, lebih jauh lagi harga produk juga akan meningkat dengan adanya selebriti tersebut. Selebriti itu bisa menjadi pendukung produk, biasanya selebriti tersebut mempunyai hubungan dan makna atau cocok dengan produk dan pelanggan. Rossiter dan Percy mengemukakan VisCAP model yang kemudian dikemukakan lagi oleh Royan (2005:15). Empat unsur tersebut adalah Visibility, Credibility, Attraction dan Power.

\section{Minat Beli}

Pengertian minat beli konsumen menurut Durianto (2003: 104), adalah sesuatu yang berhubungan rencana konsumen untuk membeli produk tertentu, serta berapa banyak unit produk yang dibutuhkan pada periode tertentu. Minat beli merupakan pernyataan mental konsumen yang merefleksikan rencana pembelian sejumlah produk dengan merek tertentu. Pengetahuan akan minat beli sangat diperlukan para pemasar 


\section{JURNAL \\ MANAJEMEN \\ INDONESIA}

Vol. 14. No. 2

Agustus 2014 untuk mengetahui minat konsumen terhadap suatu produk maupun untuk memprediksikan penolakan konsumen di masa datang.

Indikator-indikator dari minat beli dijelaskan dalam komponen dari mikro model of consumer responses (Kotler dan Keller,2012 : 503) yaitu :

1. Awareness : Sebagian konsumen tidak menyadari kebutuhan yang dimilikinya, maka dari itu tugas seorang komunikator adalah untuk menciptakan kebutuhan tersebut.

2. Knowledge : Beberapa konsumen memiliki kebutuhan akan sebuah produk, namun tidak memiliki pengetahuan yang cukup akan produk tersebut, sehingga informasi tentang produk harus bisa tersampaikan oleh komunikator.

3. Liking : Setelah konsumen mempunyai kebutuhan dan informasi, tahap selanjutnya adalah apakah konsumen menyukai produk tersebut?apabila konsumen mempunyai rasa suka, maka akan terdapat keinginan untuk membeli.

4. Preference : Setelah timbul perasaan suka terhadap produk tersebut maka konsumen perlu mengetahui perbandingan produk kita dengan produk lain, mulai dari kemasan, kualitas, nilai, performa, dan lain - lain.

5. Conviction : Konsumen telah mempunyai produk yang disukai namun belum yakin untuk melakukan proses pembelian, pada tahap ini tugas komunikator adalah meyakinkan konsumen dan menumbuhkan minat konsumen untuk membeli. Setelah melewati tahap ini Calon konsumen sudah yakin dan berminat terhadap produk tersebut.

6. Purchase : Tahap terakhir adalah tahap pembelian, beberapa target konsumen sudah yakin dan berminat tapi belum tentu akan berakhir pada pembelian, maka dari itu tugas komunikator adalah mengarahkan konsumen untuk melakukan pembelian, contohnya, memberikan diskon, layanan percobaan, ada penukaran jika barang rusak, garansi, dan lain lain

\section{METODE PENELITIAN}

Metode yang digunakan dalam penelitian ini adalah metode deskriptif kausal. Penelitian deskriptif adalah penelitian yang mendeskripsikan karakteristik dari objek, orang, grup, organisasi atau lingkungan. Tipe penelitian ini memberikan sebuah keterangan dari beberapa pertanyaan, seperti siapa yang diteliti, apa yang diteliti, kapan waktu penelitian, dimana dan bagaimana proses penelitian tersebut ( Zikmund et al, 2010 : 55). Penelitian deskriptif digunakan untuk menjawab rumusan masalah pada penelitian kali ini yaitu mengenai tanggapan responden mengenai Endorsement Fashion Blogger terhadap minat beli merek lokal. Berdasarkan latar belakang, rumusan masalah, tujuan penelitian, penelitian ini menggunakan penelitian kausal. Menurut Umar (2008:10) "Desain kausal berguna untuk mengukur hubungan-hubungan antar variabel penelitian atau berguna untuk menganalisis bagaimana suatu variabel mempengaruhi variabel lain. Variabel penelitian ini adalah Endorsement Fashion Blogger sebagai Variabel bebas (X) memiliki indikator Visibility, Credibility, Atraction, Power dan minat beli sebagai variabel terikat (Y). Skala pengukuran yang digunakan adalah skala ordinal. Skala ordinal yaitu skala yang mengurutkan data dari tingkat yang paling rendah ke tingkat yang paling tinggi atau sebaliknya dengan interval yang tidak harus sama (Umar, 2008:44). skala untuk instrument yang digunakan adalah skala likert, Menurut Zikmund et al (2010:303) skala likert adalah ukuran (skala) yang dirancang untuk memungkinkan responden untuk menilai seberapa kuat pernyataan setuju dan tidak setuju dari pernyataan yang dibangun secara hati-hati, mulai dari sangat positif hingga sangat negatif untuk obyek yang sama. Indikator-indikator tersebut dijadikan titik tolak untuk membuat item instrument yang berupa pernyataan atau pertanyaan yang perlu dijawab responden Populasi dalam penelitian ini adalah follower blog dari Evita Nuh yang berjumlah 5.822 orang. Teknik sampel yang digunakan adalah non probability sampling. 


\section{Karakteristik Responden}

Dalam penelitian ini diperlukan penetapan karakteristik responden. Karakteristik responden adalah gambaran profil responden yang menjadi sumber data penelitian. Karakteristik responden menurut usia yaitu responden yang berusia 15-17 tahun sebanyak 31 orang atau 31\%, responden yang berusia 21-23 tahun sebanyak 22 orang atau $22 \%$, kemudian responden yang berusia diatas 23 tahun sebanyak 11 orang atau $11 \%$, dan responden berusia 18-20 tahun yaitu sebanyak 36 orang atau 36\%. Karakteristik Responden Berdasarkan Pengeluaran Perbulan untuk Membeli Produk Fashion diperoleh informasi bahwa $21 \%$ atau 21 responden mengeluarkan sebesar $\leq$ Rp.100.000 perbulan untuk membeli produk fashion, $17 \%$ atau 17 responden mengeluarkan Rp.500.000 - Rp.1.000.000 perbulan, 7\% atau 7 responden mengeluarkan $>$ Rp. 1.000 .000 perbulan, dan mayoritas $55 \%$ atau 55 responden mengeluarkan Rp. 100.001 - Rp. 500.000 perbulan untuk membeli produk fashion. Hasil karakteristik responden pada tabel 4.2 sesuai dengan harga produk fashion yang dikomunikasikan Evita yang berikisar antara Rp.180.000 - Rp. 350.000.

\section{Analisis Deskriptif}

Berdasarkan hasil analisis deskriptif Endorsement Fashion Blogger secara keseluruhan berada dalam kategori sangat baik dengan nilai persentase sebesar $83,72 \%$. Visibility (X1) mencapai nilai persentase $82,25 \%$ yang termasuk dalam kategori sangat baik, Credibility (X2) mencapai nilai persentase 84,75\% termasuk dalam kategori sangat baik, Attraction (X3) mencapai nilai persentase 85,08\% termasuk dalam kategori sangat baik, dan Power (X4) mencapai nilai persentase 78,5\% termasuk dalam kategori baik. Begitu juga halnya dengan Minat Beli juga berada pada kategori Baik dengan nilai persantase rata-rata sebesar $75,40 \%$.

Tabel 3

One-Sample Kolmogorov-Smirnov Test

\begin{tabular}{|ll|r|}
\hline & & $\begin{array}{r}\text { Unstandardized } \\
\text { Predicted Value }\end{array}$ \\
\hline N & & 100 \\
Normal Parameters & & 27.0492800 \\
& Mean & Std. \\
Meviation & 3.13450053 \\
& Absolute & .079 \\
Kolmogorov-Smirnov Z & Nesitive & .079 \\
Asymp. Sig. (2-tailed) & & -.075 \\
a. Test distribution is Normal. & .786 \\
b. Calculated from data. & .567 \\
\hline
\end{tabular}

Dari tabel 3 diketahui bahwa nilai asymp sig. (2-tailed) untuk variabel X1, $\mathrm{X} 2, \mathrm{X} 3, \mathrm{X} 4$ dan Y adalah 0,567 dimana artinya adalah lebih besar dari signifikansi penelitian yaitu 0,05 . Artinya semua data-data untuk semua variabel pada penelitian ini sudah berdistribusi normal sehingga analisis jalur dapat dilakukan. 
Tabel 4

JURNAL

MANAJEMEN

INDONESIA

Vol. 14. No. 2

Agustus 2014
Korelasi antar variabel bebas

Correlations

\begin{tabular}{|l|r|r|r|r|}
\hline & $\begin{array}{c}\text { Visibilty } \\
(\mathrm{X} 1)\end{array}$ & $\begin{array}{r}\text { Credibility } \\
(\mathrm{X} 2)\end{array}$ & $\begin{array}{r}\text { Attraction } \\
(\mathrm{X} 3)\end{array}$ & $\begin{array}{c}\text { Power } \\
(\mathrm{X} 4)\end{array}$ \\
\hline Visibilty & 1 & $.407^{* *}$ & $.479^{* *}$ & $.492^{* *}$ \\
(X1) & & .000 & .000 & .000 \\
& 100 & 100 & 100 & 100 \\
Credibility & $.407^{* *}$ & 1 & $.472^{* *}$ & $.408^{* *}$ \\
(X2) & .000 & & .000 & .000 \\
& 100 & 100 & 100 & 100 \\
Attraction & $.479^{* *}$ & $.472^{* *}$ & 1 & $.760^{* *}$ \\
(X3) & .000 & .000 & & .000 \\
& 100 & 100 & 100 & 100 \\
& $.492^{* *}$ & $.408^{* *}$ & $.760^{* *}$ & 1 \\
Power (X4) & .000 & .000 & .000 & \\
& 100 & 100 & 100 & 100 \\
\hline
\end{tabular}

**. Correlation is significant at the 0.01 level (2-tailed).

4.5 Pengaruh variabel Visibility $\left(\mathrm{X}_{1}\right)$, Credibility $\left(\mathrm{X}_{2}\right)$, Attraction $\left(\mathrm{X}_{3}\right)$, Power $\left(\mathrm{X}_{4}\right)$

Tabel 4.3

Besarnnya Pengaruh Variabel secara Simultan Model Summary ${ }^{\text {b }}$

\begin{tabular}{|l|c|r|r|r|}
\hline Model & R & R Square & $\begin{array}{c}\text { Adjusted R } \\
\text { Square }\end{array}$ & $\begin{array}{c}\text { Std. Error } \\
\text { of the } \\
\text { Estimate }\end{array}$ \\
\hline 1 & $.619^{\mathrm{a}}$ & .383 & .357 & 4.06029 \\
\hline
\end{tabular}

a. Predictors: (Constant), Power (X4), Credibility

(X2), Visibilty (X1), Attraction (X3)

b. Dependent Variable: Minat Beli (Y)

Tabel 4 menunjukkan bahwa nilai R square dalam penelitian ini adalah 0,383. Nilai R square menggambarkan bahwa variabel bebas yang terdiri dari visibility, Credibility, Attraction dan Power mampu dijelaskan pengaruhnya terhadap variabel terikat yaitu Minat Beli sebesar 38,3\% oleh visibility, Credibility, Attraction dan Power, sedangkan sisanya sevesar $61,7 \%$ dijelaskan oleh faktor-faktor lain diluar variabel yang diteliti.

Tabel 5

Hasil pengujian pengaruh secara simultan

\begin{tabular}{|l|r|r|r|c|c|}
\hline Model & $\begin{array}{c}\text { Sum of } \\
\text { Squares }\end{array}$ & Df & $\begin{array}{c}\text { Mean } \\
\text { Square }\end{array}$ & F & Sig. \\
\hline Regression & 972.684 & 4 & 243.171 & 14.750 & $.000^{b}$ \\
1 Residual & 1566.162 & 95 & 16.486 & & \\
Total & 2538.846 & 99 & & & \\
\hline
\end{tabular}

a. Dependent Variable: Minat Beli (Y)

b. Predictors: (Constant), Power (X4), Credibility (X2),

Visibilty (X1), Attraction (X3)

Pengambilan keputusan pengujian hipotesis simultan ditentukan berdasarkan nilai signifikansi yaitu $\mathrm{H0}$ akan diterima jika sig $>0,05$ sedangkan $\mathrm{H} 1$ akan ditolak jika nilai sig $\leq 0,05$. Dari hasil perhitungan diperoleh bahwa nilai sig $(0,000)<\alpha(0,05)$ sehingga $\mathrm{H} 0$ ditolak dan H1 diterima. Artinya, variabel Visibility, Credibility, Attraction dan Power memiliki pengaruh yang signifikan secara simultan terhadap Minat Beli merek lokal. Besarnya variabel visibility, Credibility Attraction dan Power terhadap Minat Beli adalah sebesar 38,3\% sedangkan sisanya sebesar $61,7 \%$ dipengaruhi oleh variabel lain diluar penelitian ini. 
Pengaruh Variabel (X1), Credibility (X2),Attraction (X3), dan Power (X4) terhadap variabel Minat Beli (Y) secara parsial.

Tabel 6.

Hasil Pengujian Pengaruh Secara Parsial

Coefficients

\begin{tabular}{|c|c|c|c|c|c|}
\hline \multirow[t]{2}{*}{ Model } & \multicolumn{2}{|c|}{$\begin{array}{c}\text { Unstandardized } \\
\text { Coefficients } \\
\end{array}$} & \multirow{2}{*}{\begin{tabular}{|c}
$\begin{array}{c}\text { Standardized } \\
\text { Coefficients }\end{array}$ \\
Beta
\end{tabular}} & \multirow[t]{2}{*}{$\mathrm{t}$} & \multirow[t]{2}{*}{ Sig. } \\
\hline & B & Std. Error & & & \\
\hline (Constant) & 8.814 & 2.961 & & 2.977 & .004 \\
\hline $\begin{array}{l}\text { Credibility } \\
\text { (X2) }\end{array}$ & .707 & .236 & .282 & 2.996 & .003 \\
\hline $\begin{array}{l}\text { Power } \\
(\mathrm{X} 4)\end{array}$ & 1.710 & .699 & .312 & 2.447 & .016 \\
\hline $\begin{array}{l}\text { Visibilty } \\
\text { (X1) }\end{array}$ & .294 & .373 & .076 & .789 & .432 \\
\hline $\begin{array}{l}\text { Attraction } \\
\text { (X3) }\end{array}$ & .256 & .343 & .097 & .747 & .457 \\
\hline
\end{tabular}

Vol. 14. No. 2

Agustus 2014

a. Dependent Variable: Minat Beli (Y)

Analisis hasil pengujian hipotesis parsial penelitian ini dijabarkan sebagai berikut :

1. Pengaruh Visibility terhadap Minat Beli Merek Lokal

Hasil penghitungan pada tabel 4.11 menunjukkan bahwa nilai signifikasni variabel Visibility adalah $0,432>0,05$ sehingga $\mathrm{H} 0$ diterima dan $\mathrm{H} 1$ ditolak. Hal ini mengandung pengertian bahwa subvariabel Visibility tidak berpengaruh signifikan terhadap variabel Minat Beli Merek Lokal.

2. Pengaruh Credibility terhadap Minat Beli Merek Lokal

Hasil penghitungan pada tabel 4.11 menunjukkan bahwa nilai signifikasni variabel Credibility adalah $0,003<0,05$ sehingga $\mathrm{H} 0$ ditolak dan $\mathrm{H} 1$ diterima. Hal ini mengandung pengertian bahwa subvariabel Credibility berpengaruh signifikan terhadap variabel Minat Beli Merek Lokal.

3. Pengaruh Attraction terhadap Minat Beli Merek Lokal

Hasil penghitungan pada tabel 4.11 menunjukkan bahwa nilai signifikansi variabel Attraction adalah $0,457>0,05$ sehingga $\mathrm{H} 0$

diterima dan $\mathrm{H} 1$ ditolak. Hal ini mengandung pengertian bahwa subvariabel attraction tidak berpengaruh signifikan terhadap

variabel Minat Beli Merek Lokal.

4. Pengaruh Power terhadap Minat Beli Merek Lokal

Hasil penghitungan pada tabel 4.11 menunjukkan bahwa nilai signifikansi variabel Power adalah $0,016<0,05$ sehingga $\mathrm{H} 0$

ditolak dan $\mathrm{H} 1$ diterima. Hal ini mengandung pengertian bahwa subvariabel Power berpengaruh signifikan terhadap variabel

Minat Beli Merek Lokal.

Hasil analisis menunjukkan bahwa dari empat variabel bebas terdapat dua variabel yang tidak memiliki pengaruh signifikan terhadap Minat Beli Merek Lokal, yaitu Visibility, dan Attraction.Tidak terdapatnya pengaruh yang signifikan antara variabel Visibility (X1) dan Attraction (X3) menyebabkan perlu dilakukan perbaikan terhadap model analisis jalur melalui trimming. Menurut Heise dalam Ridwan dan Kuncoro (2007:127), model trimming terjadi ketika koefisien jalur diuji ternyata ada variabel yang tidak signifikan. Walaupun ada satu, dua, atau lebih variabel yang tidak signifikan, peneliti perlu memperbaiki model struktur analisis jalur yang telah dihipote- 


\section{JURNAL}

MANAJEMEN

INDONESIA

Vol. 14. No. 2

Agustus 2014
siskaan.Cara menggunakan model trimming yaitu menghitung ulang koefisien jalur tanpa menyertakan variabel bebas yang koefisien jalurnya tidak signifikan. Dalam penelitian ini variabel visibility dan Attraction dikeluarkan dari model dan dilakukan pengujian ulang.

\section{Pengaruh variabel Credibility (X2) dan Power(X4) terhadap variabel Minat Beli (Y) secara Simultan setelah proses Trimming.}

Tabel 7

Besarnya pengaruh variabel secara simultan setelah proses triming

\begin{tabular}{|l|c|c|c|c|}
\multicolumn{5}{c|}{ Model Summary } \\
\hline Model & R & $\begin{array}{c}\text { R } \\
\text { Square }\end{array}$ & $\begin{array}{c}\text { Adjusted R } \\
\text { Square }\end{array}$ & $\begin{array}{c}\text { Std. Error of the } \\
\text { Estimate }\end{array}$ \\
\hline 1 & $.612^{2}$ & .374 & .361 & 4.04657 \\
\hline
\end{tabular}

a. Predictors: (Constant), Power (X4), Credibility (X2)

b. Dependent Variable: Minat Beli (Y)

Tabel 7 menunjukkan bahwa nilai Rsquare dalam penelitian ini setelah proses trimming adalah 0,374. Artinya, Minat Beli mampu dijelaskan sebesar 37,4\% oleh Credibility (X2)dan Power (X4).Sedangkan sisanya sebesar 62,6\% dijelaskan oleh faktor-faktor diluar variabel yang diteliti.

Tabel 8

Hasil pengujian pengaruh secara simultan setelah proses trimming

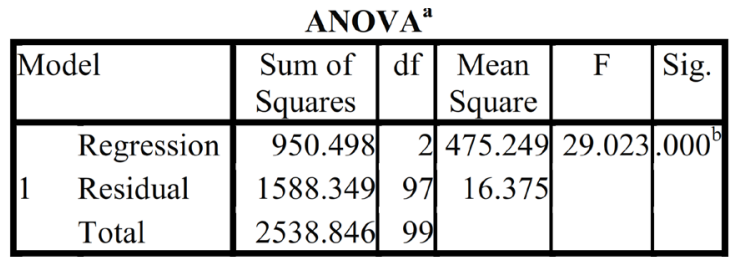

a. Dependent Variable: Minat Beli (Y)

b. Predictors: (Constant), Power (X4), Credibility (X2)

Pengambilan keputusan pada pengujian simultan ditentukan berdasarkan nilai signifikansi yaitu $\mathrm{H} 0$ akan diterima jika nilai sig $>0,05$ sedangkan $\mathrm{H} 0$ akan ditolak jika nilai sig $\leq 0,05$. Dari hasil penghitungan diperoleh bahwa nilai sig $(0,000)<\alpha$ $(0,005)$ sehingga $\mathrm{H0}$ ditolak dan $\mathrm{H} 0$ diterima. Artinya variabel Credibility dan Power memiliki pengaruh yang siginifikan secara simultan terhadap Minat Beli Merek Lokal. Besarnya pengaruh variabel Credibility dan Power terhadap Minat Beli adaah sebesar 37,4\%. Sedangkan sisanya sebesar $62,6 \%$ dipengaruhi oleh variabel lain diluar penelitian ini, seperti pendapat orang terdekat, word of mouth, dan Merek produk fashion tersebut.

Tabel 9

Pengaruh variabel Credibility (X2) dan Power (X4) terhadap variabel Minat Beli Merek Lokal (Y) secara parsial setelah proses trimming.

\begin{tabular}{|c|c|c|c|c|c|}
\hline \multirow[t]{2}{*}{ Model } & \multicolumn{2}{|c|}{$\begin{array}{c}\text { Unstandardized } \\
\text { Coefficients }\end{array}$} & $\begin{array}{l}\text { Standardized } \\
\text { Coefficients }\end{array}$ & \multirow[t]{2}{*}{$\mathrm{t}$} & \multirow[t]{2}{*}{ Sig. } \\
\hline & B & Std. Error & Beta & & \\
\hline (Constant) & 10.925 & 2.328 & & 4.694 & .000 \\
\hline $\begin{array}{l}\text { Credibility } \\
\text { (X2) }\end{array}$ & .802 & .221 & .320 & 3.634 & .000 \\
\hline $\begin{array}{l}\text { Power } \\
\text { (X4) }\end{array}$ & 2.236 & .483 & 407 & 4.632 & .000 \\
\hline
\end{tabular}

a. Dependent Variable: Minat Beli (Y) 
Analisis hasil pengujian hipotesis parsial setelah proses trimming diuraikan sebagai berikut :

1. Pengaruh Credibility terhadap Minat Beli Merek Lokal

Dari hasil penghitungan SPSS diketahui bahwa nilai signifikansi variabel Credibility setelah proses trimming adalah $0,000<0,05$, sehingga $\mathrm{H} 1$ ditolak dan H0 diterima. Artinya variabel Credibility memiliki pengaruh yang signifikan terhadap Minat Beli Merek Lokal.

2. Pengaruh Power terhadap Minat Beli Merek Lokal

Dari hasil $p$ enghitungan SPSS diketahui bahwa nilai signifikansi variabel Power setelah proses trimming adalah $0,000<0,05$, sehingga $\mathrm{H} 1$ ditolak dan $\mathrm{H} 0$ diterima. Artinya variabel Power memiliki pengaruh yang signifikan terhadap Minat Beli Merek Lokal.

\section{Perhitungan Analisis Jalur Keseluruhan}

Hasil penghitungan analisis jalur secara keseluruhan ditunjukkan pada diagram analisis jalur pada gambar 1 berikut :

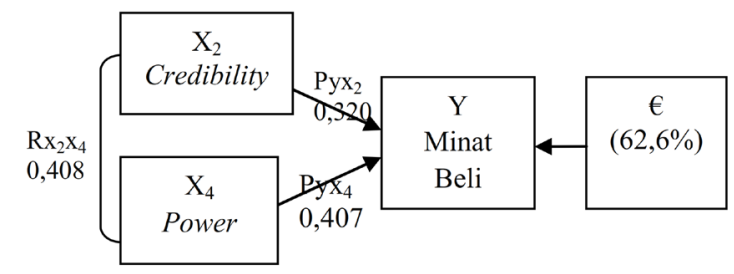

Gambar 1. Diagram Analisis Jalur Setelah Proses Trimming Sumber : (Sandjojo,2011:102)

Persamaan Struktural diagram jalur pada penelitian ini adalah ;

$\mathrm{Y}=0,320 \mathrm{X} 2+0,407 \mathrm{X} 4+0,626$

Berikut adalah uraian dari pengaruh langsung, tidak langsung, dan pengaruh total masing-masing variabel bebas dalam penelitian ini :

1. Pengaruh Variabel Credibility (X2)

Pengaruh langsung variabel Credibility (X2) terhadap Variabel Minat Beli $(\mathrm{Y})=$ $($ pyx $) 2=(0,320) 2=0,1024=10,24 \%$

Pengaruh tidak langsung variabel Credibility (X2) terhadap variabel Minat Beli (Y)

Pengaruh melalui hubungan korelatif dengan X4 $=\mathrm{PYX} 2 \times \mathrm{RX} 2 \mathrm{X} 4 \mathrm{x} \mathrm{PYX}=0,320 \mathrm{x}$ $0,408 \times 0,407=5,31 \%$

Pengaruh total variabel Credibility $(\mathrm{X} 2)$ terhadap variabel Minat Beli $(\mathrm{Y})=10,24 \%+$ $5,31 \%=15,55 \%$

2. Pengaruh Variabel Power (X4)

Pengaruh langsung Variabel Power $(X 4)$ terhadap variabel Minat Beli $(Y)=($ pyx4 $) 2=$ $0,4072=16,56 \%$

Pengaruh tidak langsung variabel Power (X4) terhadap Minat Beli (Y).

Pengaruh melalui hubungan korelatif dengan X2 $=(\mathrm{PYX} 4 \times \mathrm{RX} 2 \mathrm{X} 4 \times \mathrm{PYX} 4)=$ $0,407 \times 0,408 \times 0,320=5,31 \%$

Pengaruh Total variabel Power $(\mathrm{X} 4)$ terhadap Minat Beli $(\mathrm{Y})=16,56 \%+5,31=21,87$ 


\section{JURNAL}

MANAJEMEN

INDONESIA

Vol. 14. No. 2

Agustus 2014

\section{Analisis Koefisien Determinasi \\ Tabel 10. \\ Hasil Uji Koefisien Determinasi Model Summary}

\begin{tabular}{|c|c|c|c|c|c|}
\hline $\begin{array}{c}\text { Mo } \\
\text { del }\end{array}$ & $\mathrm{R}$ & $\begin{array}{c}\mathrm{R} \\
\text { Squar } \\
\mathrm{e}\end{array}$ & $\begin{array}{c}\text { Adjusted } \\
\mathrm{R} \text { Square }\end{array}$ & $\begin{array}{c}\text { Std. } \\
\text { Error of } \\
\text { the } \\
\text { Estimate }\end{array}$ & $\begin{array}{c}\text { Durbin- } \\
\text { Watson }\end{array}$ \\
\hline 1 &, $483^{\mathrm{a}}$ &, 233 &, 224 &, 3915 & 1,882 \\
\hline
\end{tabular}

a. Predictors: (Constant), kompensasi tidak langsung, kompensasi langsung

b. Dependent Variable: motivasi kerja

b. Dependent Variable: motivasi kerja Berdasarkan output pada tabel 4.9, maka dapat diketahui koefisien determinasi untuk pengaruh kompensasi langsung dan kompensasi tidak langsung terhadap motivasi kerja adalah sebagai berikut:

$$
\begin{aligned}
\mathrm{KD} & =(\mathrm{R} 2 \text { Square }) \times 100 \% \\
& =0,233 \times 100 \% \\
& =23,3 \%
\end{aligned}
$$

Nilai koefisien determinasi diperoleh sebesar 23,3\%. Hal ini menunjukkan bahwa pada model regresi berganda ini menjelaskan bahwa persentase sumbangan pengaruh kompensasi langsung (X1) dan kompensasi tidak langsung (X2) terhadap motivasi kerja (Y) karyawan Kantor Distribusi PT.PLN (Persero) Distribusi Jawa Barat dan Banten adalah sebesar 23,3\%. Sedangkan sisanya sebesar 76,7\% dipengaruhi oleh faktor lain yang tidak dibahas dalam penelitian ini.

\section{KESIMPULAN DAN SARAN}

\section{Kesimpulan}

Berdasarkan penelitian yang dilakukan maka dapat diterik beberapa kesimpulan yang diharapkan dapat menjawab tujuan dilakukannya penelitian ini, yaitu sebagai berikut :

1. Endorsement Fashion Blogger yang terdiri dari sub variabel Visibility, Credibility, Attraction, dan Power mendapat tanggapan responden sebesar 83,72\% atau berada pada kategori sangat baik. Hal ini berarti Evita merupakan sosok fashion Blogger yang terkenal karena memiliki penggemar yang banyak dan cukup sering tampil di majalah-majalah dan media elektronik seperti di internet. Selain itu Evita juga mempunyai pengetahuan yang tinggi di bidang fashion dan tentu saja tentang produk yang dikomunikasikan oleh Evita. Sehingga pendapat Evita tentang fashion dipercaya oleh audiences.Dari variabel attraction dapat dilihat Evita mempunyai daya tarik yang tinggi sebagai endorser, baik dilihat dari penampilan fisik atau kepribadian.

2. Minat Beli Merek Lokal mendapat tanggapan sebesar 75,4\% atau termasuk pada kategori baik. Hal ini berarti sebagian besar responden memiliki kesadaran akan kebutuhan fashion, memperhatikan produk - produk Fashion Lokal yang ada di blog Evita, dan tertarik dengan produk merek lokal yang dikomunikasikan oleh Evita, tetapi responden kurang mengetahui apa saja merek lokal yang dikomunikasikan Evita hal ini mungkin disebabkan banyaknya merek lokal yang dikomunikasikan Evita, sehingga responden tidak mengetahui dengan detail apa saja merek lokal yang bekerjasama dengan Evita. 
kal pada blog Evita Nuh setelah dilakukan pengujian ulang melalui trimming adalah secara simultan variabel Credibility dan Power memiliki pengaruh yang signifikan sebesar 37,4\% sedangkan sebesar 62,6\% dipengaruhi oleh variabel-variabel lain diluar penelitian ini. Hasil penelitian juga menunjukkan bahwa variabel Visibility,dan Attraction tidak memiliki pengaruh yang signifikan terhadap Minat Beli Merek Lokal yang dikomunikasikan Evita.

Saran

Berdasarkan kesimpulan pada hasil penelitian mengenai Endorsement Fashion Blogger Evita Nuh terhadap Minat Beli Merek Lokal, maka penulis mencoba memberikan masukan berupa saran-saran sebagai berikut :

\section{Saran Untuk Fashion Blogger Evita Nuh}

Power merupakan salah satu sub-variabel yang signifikan, oleh karena itu Evita harus meningkatkan kemampuannya mempengaruhi minat responden untuk membeli produk fashion lokal yang dikomunikasikannya. Hal ini dapat dilakukan dengan cara mulai menerima tawaran untuk tampil di televisi misalnya program-program talkshow, Evita harus lebih sering mengupdate postnya tentang fashion secara terjadwal di blognya, dan lebih memilih produk fashion lokal yang akan dikomunikasikan oleh Evita.

\section{Saran Untuk Penelitian Selanjutnya}

Diharapkan bagi peneliti selanjutnya bisa melakukan penelitian mengenai Endorsement Fashion Blogger dengan sub variabel lain seperti TEARS (Trustworthness, Expertise, Attractiveness, Respect, dan Similarity) dan penelitian mengenai Endorsement Fashion Blogger dengan Variabel keputusan pembelian konsumen merek lokal tertentu sehingga dapat mengetahui lebih dalam tentang Endorsement Fashion Blogger.

\section{DAFTAR PUSTAKA}

Businessnewsdaily. (2011, April 19). Need a product endorsement? Look to bloggers notcelebrities.Tersedia: http://businessnewsdaily.com [28 mei 2013]

Durianto, Darmanto. (2003). Invasi pasar iklan yang efektif.Jakarta : Gramedia.

Kompas.(2011, Oktober 19). Majukan Local brand Indonesia. Tersedia :http://forum. kompas.com [17 juni 2013]

Kotler, Philip dan Keller, Kevin Lane. (2012). Marketing manajemen 14 th edition. New Jersey: Pearson Education, Inc.

Menparekraf .(2013, Februari 14).Perkembangan Industri fashion menggembirakan. Tersedia :htpp://budpar.go.id [12 Juni 2013]

Merean.(2012). 10 incredibly fab style blogs from Indonesia. Tersedia : http://fashion. allwomenstalk.com[27 mei 2013]

Royan, Frans M. (2005). Marketing selebritis, selebritis dalam iklan dan strategi selebriti memasarkan diri sendiri.Jakarta : PT. Elex Media Komputindo.

Sandjojo, Nidjo. (2011). Metode analisis jalur (path analysis dan aplikasinya.Jakarta : Pustaka Sinar Harapan.

Schiffman, Leon G. \& Kanuk, Leslie lazar.(2010). Consumen Behavior.10/E.Boston : Pearson.

Shimp, Terence. A. (2003).Periklanan promosi komunikasi pemasaran terpadu.Jakarta : Erlangga

Suyanto, M. (2007).Marketing strategy : Top Brand Indonesia. Yogyakarta : ANDI

Zikmund, William G.et,al. (2010). Business research methods (eigth edition).South western.USA : Cengage Learning 
